\title{
NOTES
}

\section{Base Composition of DNA from Selected Strains of the Cyanobacterial Genus Microcystis}

\author{
PAULA M. FAHRENKRUG, ${ }^{1}$ MARY B. BETT,${ }^{2}$ AND DOROTHY L. PARKER ${ }^{1 *}$ \\ Department of Biology and Microbiology, University of Wisconsin at Oshkosh, Oshkosh, Wisconsin $54901,{ }^{1}$ \\ and Department of Plant Pathology, University of Wisconsin at Madison, Madison, Wisconsin 53715
}

\begin{abstract}
Average DNA base compositions, as determined from $50 \%$ thermal denaturation temperatures and from buoyant densities, were 38, 41, 43, and 40 to $41 \mathrm{~mol} \% \mathrm{G}+\mathrm{C}$ for Microcystis sp. strains P1-15, C5-34, AK1-6, and C3-40, respectively. These phenotypically similar organisms, which are representatives of the Microcystis cluster within the Synechocystis group of chroococcacean cyanobacteria, have a smaller range of DNA base compositions (38 to $43 \mathrm{~mol} \% \mathrm{G}+\mathrm{C}$ ) than the Synechocystis group as a whole does (30 to $48 \mathrm{~mol} \% \mathrm{G}+\mathrm{C}$ ). Because the DNA base ratios of the Microcystis cultures adjoin or overlap those of the low- and high-G+Ccontent clusters of the Synechocystis group, DNA base composition data do not differentiate the Microcystis cluster from these two Synechocystis clusters. By bridging the gap between the low- and high-G+C-content clusters of the Synechocystis group, the data for Microcystis create a continuum of DNA base ratios within the Synechocystis group and diminish the usefulness of $\mathrm{G}+\mathrm{C}$ values for discerning clusters within the phenotypically heterogeneous Synechocystis group.
\end{abstract}

Unicellular cyanobacteria that divide in two or three successive planes at right angles to one another have been provisionally assigned to an assemblage designated the $S y n-$ echocystis group $(8-10,12,19-21,23)$, which consists of the following four strain clusters: the marine cluster, the low$\mathrm{G}+\mathrm{C}$-content cluster, the high-G+C-content cluster, and the Microcystis cluster (24). The four clusters are "equivalent to genera but have not been formalized because their characterization is based on an incomplete data set, with a relatively limited number of phenotypic properties used" (24). For brevity and for consistency with previous publications, organisms belonging to the Microcystis cluster are referred to below as Microcystis strains, without implying more than a provisional taxonomic conclusion.

Previously, the DNA base composition of only one Microcystis culture, strain ATCC 27153 (= PCC 7005), has been determined (23). Below we describe a method for extracting DNAs from additional axenic Microcystis sp. cultures and report their DNA base compositions as estimated from $50 \%$ thermal denaturation temperatures $\left(T_{m}\right)$ and from buoyant densities in $\mathrm{CsCl}$ gradients.

Cultures. The purification, origins, morphologies, and certain properties of Microcystis sp. strain P1-15, C5-34, AK1-6, and C3-40 (a subclone of strain C3-9) have been described previously $(7,16)$. All other cultures were obtained from the American Type Culture Collection.

DNA extraction. Calf thymus DNA $(3,17)$ and Micrococcus luteus DNA (2) were obtained from Sigma Chemical Co. DNAs from Escherichia coli ATCC E25404 $(1,6)$ and Salmonella typhimurium ATCC 15277 (1) were extracted by using the Marmur method (14) and cells grown on brain heart infusion agar (Difco). Cyanobacterial cultures in Jansen medium (4) were grown at 26 to $30^{\circ} \mathrm{C}$ without shaking and with continuous irradiance of 15 to 30 microeinsteins $\mathrm{m}^{-2}$ $\mathrm{s}^{-1}(1,076$ to $2,152 \mathrm{~lx})$ from cool-white fluorescent lights to a

\footnotetext{
* Corresponding author
}

density of $10^{7}$ to $10^{8}$ cells per $\mathrm{ml}$. Cells from each culture were washed three times by suspension and centrifugation in double-distilled water. Each cell pellet ( 2 to $3 \mathrm{~g}$, wet weight) was resuspended in $15 \mathrm{ml}$ of saline EDTA $(0.15 \mathrm{M} \mathrm{NaCl}$ in $0.01 \mathrm{M}$ sodium EDTA, $\mathrm{pH}$ 8). The cell suspension was sequentially treated by adding $15 \mathrm{mg}$ of lysozyme (Sigma), incubating the preparation for $45 \mathrm{~min}$ at $37^{\circ} \mathrm{C}$, adding $1 \mathrm{ml}$ of $20 \%(\mathrm{wt} / \mathrm{vol})$ sodium dodecyl sulfate, incubating the preparation for an additional $45 \mathrm{~min}$ at $37^{\circ} \mathrm{C}$, adding $2.5 \mathrm{ml}$ of $5 \mathrm{M}$ sodium perchlorate, and extracting the preparation with an equal volume of chloroform-isoamyl alcohol $(23: 1$, vol/vol $)$ at $20^{\circ} \mathrm{C}$ for $30 \mathrm{~min}$. The DNA was precipitated with ethanol and resuspended in $2 \mathrm{ml}$ of $0.1 \times \mathrm{SSC}$ buffer, which was then adjusted to $1 \times \mathrm{SSC}(0.15 \mathrm{M} \mathrm{NaCl}$ plus $0.015 \mathrm{M}$ trisodium citrate, $\mathrm{pH}$ 7.0). This solution was incubated with $50 \mu \mathrm{g}$ of pancreatic RNase at $37^{\circ} \mathrm{C}$ for $30 \mathrm{~min}$ and then extracted at least twice with phenol-chloroform $(1: 1, \mathrm{vol} / \mathrm{vol})(5)$. For $T_{m}$ analysis, the DNA was further purified by hydroxylapatite column chromatography (18). The yields of cyanobacterial DNA averaged $164 \mu \mathrm{g}$ of DNA per g (wet weight) of "cells. The UV absorbance spectra between 190 and $300 \mathrm{~nm}$ were as predicted for good-purity nucleic acid (11); the ratios of $A_{260}$ to $A_{280}$ were $\geq 1.80$ (range, 1.80 to 2.14 ), and the ratios of $\dot{A}_{260}$ to $A_{230}$ were $\geq 2.01$ (range, 2.01 to 5.00 ).

Thermal denaturation. Thermal denaturation of DNA was examined by using the method of Mandel and Marmur (13). A $10-\mu \mathrm{g}$ portion of DNA in $1 \mathrm{ml}$ of $0.1 \times \mathrm{SSC}$ was heated at a rate of $1.0^{\circ} \mathrm{C}$ per min in a Perkin-Elmer model 552 spectrophotometer equipped with a 10-cell heatable chamber that allowed parallel examination of control DNA. Table 1 shows the $T_{m}$ data.

Buoyant densities. Buoyant densities were measured by using the method of Meselson et al. (15), modified as described below. Tris- $\mathrm{HCl}$ buffer $(0.02 \mathrm{M} 2$-amino-2 hydroxymethyl-1,3-propanediol, $\mathrm{pH} 8.5$ ) containing 54 to 320 $\mu \mathrm{g}$ of test DNA per ml and 5.8 to $17.4 \mu \mathrm{g}$ of internal standard Micrococcus luteus DNA per $\mathrm{ml}$ was adjusted to a final density of $1.710 \mathrm{~g} / \mathrm{ml}$ by adding optical grade CsCl (U.S. 
TABLE 1. Mean DNA base compositions as determined by $T_{m}$ and buoyant density measurements

\begin{tabular}{|c|c|c|c|c|c|}
\hline \multirow{3}{*}{ Source of DNA } & \multirow{3}{*}{$T_{m}\left({ }^{\circ} \mathrm{C}\right)^{a}$} & \multirow{3}{*}{$\begin{array}{l}\text { Buoyant density } \\
\qquad(\mathrm{g} / \mathrm{ml})^{b}\end{array}$} & \multicolumn{3}{|c|}{$\mathrm{G}+\mathrm{C}$ content $(\mathrm{mol} \%)$} \\
\hline & & & \multicolumn{2}{|c|}{ This study } & \multirow{2}{*}{$\begin{array}{l}\text { Other } \\
\text { studies }\end{array}$} \\
\hline & & & $T_{m}$ method & $\begin{array}{l}\text { Buoyant density } \\
\text { method }\end{array}$ & \\
\hline Calf thymus & $75.4 \pm 0.8$ & $1.6991 \pm 0.0000$ & 42 & 40 & $42,{ }^{c} 39^{d}$ \\
\hline E. coli $\mathrm{E} 25404$ & $78.9 \pm 1.9$ & $1.7086 \pm 0.0013$ & 50 & 50 & $50,^{e} 51^{f}$ \\
\hline Micrococcus luteus & $\mathrm{ND}^{g}$ & $1.7306 \pm 0.0000$ & ND & 72 & $72^{h}$ \\
\hline S. typhimurium 15277 & $79.4 \pm 0.8$ & ND & 51 & ND & $50^{e}$ \\
\hline Synechocystis sp. strain $27150^{\mathrm{T}}$ & $72.3 \pm 2.5$ & $1.6942 \pm 0.0006$ & 36 & 35 & $35,^{i} 35^{j}$ \\
\hline Synechocystis sp. strain $27178^{\mathrm{T}}$ & ND & $1.7057 \pm 0.0009$ & ND & 47 & $47,^{i} 48^{k}$ \\
\hline Microcystis sp. strain P1-15 & $73.1 \pm 0.9$ & ND & 38 & ND & ND \\
\hline Microcystis sp. strain C3-40 & $74.7 \pm 0.6$ & $1.6996 \pm 0.0006$ & 41 & 40 & ND \\
\hline Microcystis sp. strain C5-35 & $74.8 \pm 1.8$ & ND & 41 & ND & ND \\
\hline Microcystis sp. strain AK1-6 & $75.9 \pm 0.5$ & ND & 43 & ND & ND \\
\hline
\end{tabular}

${ }^{a}$ For most organisms the data are means \pm standard deviations for three replicates from individually grown cultures; duplicate cultures were used for the Synechocystis sp. strain $27150^{\mathrm{T}}$ and Microcystis sp. strain C5-34 determinations.

${ }^{b}$ For most organisms the data are means \pm standard deviations for four replicates from individually grown cultures; duplicate cultures were used for calf thymus determinations, and six replicates were used for Microcystis sp. strain C3-40 determinations.

${ }^{c}$ Data from reference 3.

${ }^{d}$ Data from reference 17

e Data from reference 1

${ }^{f}$ Data from reference 6 .

${ }^{g} \mathrm{ND}$, not determined.

${ }^{h}$ Data from reference 2 .

'Data from reference 23.

${ }^{j}$ Data from reference 8.

${ }^{k}$ Data from reference 10 .

Biochemical Corp.). This solution was centrifuged for 48 to $70 \mathrm{~h}$ at $35,000 \mathrm{rpm}(85,000 \times \mathrm{g})$ in a type $50 \mathrm{Ti}$ rotor in a Beckman model L5-50 ultracentrifuge at $25^{\circ} \mathrm{C}$. Fractions $(5$ drops) were collected from the bottom of the centrifuge tube and stored in tightly sealed vials. The densities of fractions were determined from refractive indices measured with a Valentine refractometer. To each fraction we added $0.2 \mathrm{ml}$ of $0.1 \mathrm{M}$ Tris- $\mathrm{HCl}$ buffer ( $\mathrm{pH} \mathrm{8.4)}$, and the $A_{260}$ values were determined with a Beckman model 35 spectrophotometer. Table 1 shows the buoyant density of each DNA sample and the corresponding $\mathrm{G}+\mathrm{C}$ content, which was calculated as described by Schildkraut et al. (22).

DNA base composition. For all of the DNA samples which we analyzed, the $\mathrm{G}+\mathrm{C}$ compositions calculated from the $T_{m}$ data were in agreement with the $\mathrm{G}+\mathrm{C}$ compositions calculated from buoyant densities (Table 1). Both methods yielded data for controls that were consistent with the following previously published $\mathrm{G}+\mathrm{C}$ values: 39 to $42 \mathrm{~mol} \%$ for calf thymus DNA $(3,17), 50$ to $51 \mathrm{~mol} \%$ for $E$. coli DNA $(1,6), 50$ mol\% for $S$. typhimurium DNA (1), 72 mol\% for Micrococcus luteus DNA (2), $35 \mathrm{~mol} \%$ for Synechocystis sp. strain $27150^{\mathrm{T}}$ ( $\mathrm{T}=$ type strain) DNA $(8,23)$, and 47 to 48 mol\% for Synechocystis sp. strain $27178^{\mathrm{T}}$ DNA $(10,23)$. The latter two organisms are the type strains of the low- and high-G + C-content clusters of the Synechocystis group, respectively $(9,10,23)$.

The various Microcystis cultures had fairly similar base compositions ( 38 to $43 \mathrm{~mol} \% \mathrm{G}+\mathrm{C}$ ) (Table 1). When the value of $45 \mathrm{~mol} \% \mathrm{G}+\mathrm{C}$ that has been reported previously for Microcystis sp. strain ATCC 27153 (24) is included, the range of $\mathrm{G}+\mathrm{C}$ contents for all currently characterized $\mathrm{Mi}$ crocystis cultures is 38 to $45 \mathrm{~mol} \%$. These $\mathrm{G}+\mathrm{C}$ values are greater than the values published previously (24) for the marine Synechocystis cluster (30 to $32 \mathrm{~mol} \% \mathrm{G}+\mathrm{C}$ ), are contiguous with the values for the low-G+C-content Synechocystis cluster ( 35 to $37 \mathrm{~mol} \% \mathrm{G}+\mathrm{C}$ ), and overlap the values for the high-G+C-content Synechocystis cluster (42 to $48 \mathrm{~mol} \% \mathrm{G}+\mathrm{C}$ ). Because of insufficient differences, DNA base composition cannot be used to distinguish the latter two clusters from the Microcystis cluster. In fact, the values for Microcystis cultures bridge the gap between the values for the low- and high-G $+\mathrm{C}$-content clusters, creating a continuum of DNA base ratios within the Synechocystis group and potentially eliminating one of the primary criteria for separating the low- and high-G+C-content clusters of the Synechocystis group.

It should be noted, however, that the two $\mathrm{G}+\mathrm{C}$ clusters of the Synechocystis group differ in phenotypic properties, including the occurrence of facultative heterotrophy, the presence of phycoerythrin, the polyunsaturated fatty acid content, and cell size (24). Likewise, the Microcystis cultures share several characteristics that are generally absent in Synechocystis cultures, as discussed below. Although the Synechocystis group is a phenotypically heterogeneous assemblage with a wide range of DNA base ratios (24), the Microcystis cultures have similar phenotypes $(4,7,16)$ and have a limited range of base compositions (Table 1). Therefore, we favor the continued provisional recognition of the various clusters within the Synechocystis group until data concerning levels of DNA homology, levels of rRNA similarity, and additional phenotypic properties are available.

The Microcystis cultures in Table 1 are organisms that have similar ecology and morphology $(4,7,16)$. All were isolated from planktonic organisms in eutrophic, alkaline, freshwater lakes or rivers in the midwestern United States. All produce spherical cells with prominent gas vesicles. At the time of culture isolation, all occurred in large multicellular aggregates within copious capsules or slime layers, which are still formed by strains P1-15, C3-40, and AK1-6 although not by strain C5-34 $(4,7,16)$. The cell diameters under standard growth conditions are between 3.5 and $8 \mu \mathrm{m}$ (3.6 $\pm 0.5 \mu \mathrm{m}$ for strain P1-15 [7], 4 to $5 \mu \mathrm{m}$ for strain C5-34 
[16], and 6 to $8 \mu \mathrm{m}$ for strain $\mathrm{C} 3-9$ and its subclone, $\mathrm{C} 3-40$ [16]). Several of these properties are characteristic of the genus Microcystis but not of the Synechocystis clusters. In particular, gas vesicles are present in six of the seven organisms assigned by Waterbury and Rippka to the Microcystis cluster, but in none of the cultures of the Synechocystis clusters (24). The diameters of the Microcystis cells are larger than the values of 2 to $3 \mu \mathrm{m}$ observed for members of the high-G+C-content Synechocystis cluster (24). Several Microcystis cultures differ from Synechocystis cultures in the production of toxin(s), $\beta$-cyclocitral, or cell aggregates involving a capsule $(7,16,24)$. Because Microcystis isolates share several phenotypic properties that are often absent from other members of the Synechocystis group, it is not too surprising that these isolates have a relatively narrow range of DNA base compositions compared with the Synechocystis group as a whole.

As originally isolated, strain C5-34 exhibited the morphology of Microcystis aeruginosa (16), whereas the other Microcystis strains in Table 1 corresponded to Microcystis flos-aquae $(7,16)$. The $\mathrm{G}+\mathrm{C}$ composition of strain $\mathrm{C} 5-34$ is in the middle of the range of $\mathrm{G}+\mathrm{C}$ values for the three Microcystis flos-aquae cultures and thus does not differ from the $\mathrm{G}+\mathrm{C}$ composition of Microcystis flos-aquae.

\section{REFERENCES}

1. Bolozorsky, A. N., and A. S. Spirin. 1960. Chemistry of the nucleic acids of microorganisms, p. 147-185. In E. Chargaff and J. N. Davidson (ed.), The nucleic acids, vol. 3. Academic Press, Inc., New York.

2. Bohácek, J., M. Kocur, and T. Martinec. 1967. DNA base composition and taxonomy of some micrococci. J. Gen. Microbiol. 46:369-376.

3. Chargaff, E. 1955. Isolation and composition of the deoxypentose nucleic acids and of the corresponding nucleoproteins, $p$. 307-371. In E. Chargaff and J. N. Davidson (ed.), The nucleic acids, vol. 1. Academic Press, Inc., New York.

4. Corbett, L. L., and D. L. Parker. 1976. Viability of lyophilized cyanobacteria (blue-green algae). Appl. Environ. Microbiol. 32:777-780.

5. Davis, L. G., M. D. Dibner, and J. F. Battey. 1986. Basic methods in molecular biology. Elsevier Science Publishing Co., New York.

6. De Ley, J. 1970. Reexamination of the association between melting point, buoyant density, and chemical base composition of deoxyribonucleic acid. J. Bacteriol. 101:738-754.

7. Doers, M. P., and D. L. Parker. 1988. Properties of Microcystis aeruginosa and $M$. flos-aquae (Cyanophyta) in culture: taxonomic implications. J. Phycol. 24:502-508.

8. Edelman, M., D. Swinton, J. A. Schiff, H. T. Epstein, and B. Zeldin. 1967. Deoxyribonucleic acid of the blue-green algae
(Cyanophyta). Bacteriol. Rev. 31:315-331.

9. Efremova, L. P., and I. A. Avilov. 1978. Base composition and DNA content in some unicellular cyanobacteria. Microbiology (Engl. Transl. Mikrobiologiya) 47:378-381.

10. Herdman, M., M. Janvier, J. B. Waterbury, R. Rippka, and R. Y. Stanier. 1979. Deoxyribonucleic acid base composition of cyanobacteria. J. Gen. Microbiol. 111:63-71.

11. Johnson, J. L. 1985. Determination of DNA base composition, p. 1-31. In G. Gottschalk (ed.), Methods in microbiology, vol. 18. Academic Press, Inc., New York.

12. Komárek, J., and K. Anagnostidis. 1986. Modern approach to the classification system of cyanophytes. 2. Chroococcales. Arch. Hydrobiol. Suppl. 73:157-226.

13. Mandel, M., and J. Marmur. 1968. Use of ultraviolet absorbance-temperature profiles for determining the guanine plus cytosine content of DNA. Methods Enzymol. 12B:195-206.

14. Marmur, J. 1961. A procedure for the isolation of deoxyribonucleic acid from micro-organisms. J. Mol. Biol. 3:208-218.

15. Meselson, M., F. W. Stahl, and J. Vinograd. 1957. Equilibrium sedimentation of macromolecules in density gradients. Proc. Natl. Acad. Sci. USA 43:581-590.

16. Parker, D. L. 1982. Improved procedures for the cloning and purification of Microcystis cultures (Cyanophyta). J. Phycol. 10:471-477.

17. Polli, E., G. Corneo, E. Ginelli, and P. Bianchi. 1965. Fractionation of calf thymus deoxyribonucleic acid by density-gradient centrifugation. Biochim. Biophys. Acta 103:672-677.

18. Price, C. W., G. B. Fuson, and H. J. Phaff. 1978. Genome comparison in yeast systematics: delimitation of species within the genera Schwanniomyces, Saccharomyces, Debaryomyces, and Fichia. Microbiol. Rev. 42:161-193.

19. Rippka, R. 1988. Recognition and identification of cyanobacteria. Methods Enzymol. 167:28-67.

20. Rippka, R., J. Deruelles, J. B. Waterbury, M. Herdman, and R. Y. Stanier. 1979. Generic assignments, strain histories and properties of pure cultures of cyanobacteria. J. Gen. Microbiol. 111:1-61.

21. Rippka, R., J. B. Waterbury, and R. Y. Stanier. 1981. Provisional generic assignments for cyanobacteria in pure culture, $\mathrm{p}$. 247-256. In M. P. Starr, H. Stolp, H. G. Trüper, A. Balows, and H. D. Schlegel (ed.), The prokaryotes. A handbook on habitats, isolation, and identification of bacteria. Springer-Verlag, New York.

22. Schildkraut, C. L., J. Marmur, and P. Doty. 1962. Determination of the base composition of deoxyribonucleic acid from its buoyant density in $\mathrm{CsCl}$. J. Mol. Biol. 4:430 443 .

23. Stanier, R. Y., R. Kunisawa, M. Mandel, and G. Cohen-Bazire. 1971. Purification and properties of unicellular blue-green algae (order Chroococcales). Bacteriol. Rev. 35:171-205.

24. Waterbury, J. B., and R. Rippka. 1989. Subsection I. Order Chroococcales Wettstein 1924, Emend. Rippka et al., 1979, p. 1728-1746. In J. T. Staley, M. P. Bryant, N. Pfenning and J. G. Holt (ed.), Bergey's manual of systematic bacteriology, vol. 3 . The Williams \& Wilkins Co., Baltimore. 